\title{
Estimation of in situ stress using the memory technique for deep mining
}

\author{
PM Dight Australian Centre for Geomechanics, The University of Western Australia, Australia \\ BG Tarasov Centre for Offshore Foundation Systems, The University of Western Australia, Australia
}

A Hsieh Australian Centre for Geomechanics, The University of Western Australia, Australia

AV Dyskin School of Civil, Environmental and Mining Engineering, The University of Western Australia, Australia

\begin{abstract}
A series of tests are described in which the in situ stress has been recovered using the rock memory technique, known as deformation rate analysis (DRA), where the samples have been subjected to confinement ( 30 and $50 \mathrm{MPa}$ ). The rock samples comprised Urad Aplite Porphyry and were recovered from oriented core, drilled from a depth of approximately 1,550-1,650 m below surface lower than the current mine development. The oriented core is subsampled to obtain the test samples in six directions. The tests were performed in a sophisticated, very stiff triaxial stress cell. The unconfined compressive strength (UCS) of the rock was approximately $70 \mathrm{MPa}$. The maximum in situ stress was determined to be approximately $70 \mathrm{MPa}$. Based on experience the test procedure adopted typically loads the samples to a stress equal to three times the estimated overburden stress. In this case, that would be approximately $120 \mathrm{MPa}$, which would clearly exceed the UCS and hence the unconfined memory test would not have been applicable. Testing under confinement can increase the measurable stress difference, i.e. $\sigma_{1}-\sigma_{3}$, and thus significantly extend the depth to which this technique can be undertaken when compared with unconfined tests suitable for other memory techniques. In particular, in the tests conducted, the confinement of 30 and $50 \mathrm{MPa}$ raised the strength $\left(\sigma_{1}-\sigma_{3}\right)$ from $70 \mathrm{MPa}$ to between 170-270 MPa. Such an approach has implications for testing rock samples recovered from deep drilling where conventional testing could not reach the expected in situ stress without premature failure of the samples.
\end{abstract}

\section{$1 \quad$ Background}

This paper presents the results of a stress measurement program conducted for the Henderson Mine. Some of the samples were tested unconfined and some with confinement. One sample was recovered from borehole HEND 0782, two from borehole HEND 0784 and one from HEND 0783 (1,616 m). All samples were located in Urad Aplite Porphyry at depth of 1,550-1,650 m below ground level. The stresses have been determined using DRA (deformation rate analysis). In HEND 783 the material had a high porosity and low unit weight (average $23.6 \mathrm{kN} / \mathrm{m}^{3}$ ). The stresses have been determined using DRA in terms of magnitude and orientation and seismic velocity using orientation only.

The DRA technique was first reported by K Yamamoto in Japan in 1990 (Yamamoto et al. 1990). Dight used the technique at Argyle in $\mathbf{2 0 0 2}$ where it was shown it replicated the hydraulic fracture results almost exactly for magnitude and orientation. The method can provide both the Kaiser effect and the in situ stress. The use of seismic velocity to identify the principal stress directions has been developed in the past (Nur \& Simmons 1969; Nur 1971; Engelder et al. 1984; Plumb et al. 1984; Sayers 1990) and the method provided references of principal stress direction in Hsieh's PhD project on stress memory (Hsieh 2014). 
DRA has been used to provide stress measurement results for a number of projects including:

- Rio Tinto's Argyle Block Cave (confirmed by hydraulic fracture (HF) testing and hydraulic inclusion (HI) testing).

- Tritton Copper Mine (where it was also demonstrated that the $\mathrm{HI}$ cell was very sensitive to anisotropy in the rock.

- St Barbara's Gwalia Deeps Mine (where it was shown that the stress field was no longer 3:1 but closer to $1.6: 1$ below $1,000 \mathrm{~m}$ - which has now been confirmed independently by $\mathrm{HI}$ cell measurements) (Dight \& Snyman 2010).

- Aguas Teñidas Copper Project, Spain (where testing was undertaken on a block of rock recovered from the side wall of a drive) - these results were independently verified using the borehole slotter from Interfels.

- Goldfields Agnew mine.

- MMG's Golden Grove (confirmed with HI cell test work).

- Newmont's Boddington Gold Mine.

- Posiva, Finland (tested against many other techniques).

- Barrick's Reko Diq Copper project (Pakistan).

- Newcrest's Cadia East Mine (testing against HI program).

- Western Areas Flying Fox.

- Sandfire's DeGrussa Project.

A large number of blind tests on overcore recovered from $\mathrm{HI}$ cell tests have been undertaken as part of a research project. The results are confidential but confirm the robustness of the technique.

\section{$2 \quad$ Testing under confinement}

Many rock samples recovered from depth have unconfined strengths which are similar to the overburden stress. If these rocks are tested without confinement there is a high probability that the stress memory will not be recovered before the rocks break. Dight et al. (2013) showed that rock memory can be recovered using confined tests. The advantage is that the confined strength is significantly higher than the unconfined strength thus greatly extending the range of the method.

While the strength of the rock at Henderson has been reported to be between 100 and $250 \mathrm{MPa}$, the rock from HEND 0783 appeared much weaker. The unit weight was $23 \mathrm{kN} / \mathrm{m}^{3}$. Hence, it was considered that the in situ stress could be recovered using confinement.

\section{Program}

This paper presents the results of a stress measurement program for four samples recovered from boreholes HEND 0782, HEND 0784 and HEND 0783 for the Henderson Project. The holes were oriented with trend and plunge of $003^{\circ} / 60^{\circ}, 114^{\circ} / 65^{\circ}$ and $240^{\circ} / 60^{\circ}$ respectively. The first sample (as test 782 ) was recovered from HEND 0782 at a depth below surface of 1,549 $\mathrm{m}$. The second (as test 784S) and third (as test 784D) samples were recovered from 1,614 and 1,637 $\mathrm{m}$ below surface respectively, while the fourth sample was recovered from $1,617 \mathrm{~m}$ below surface.

The layout of the level and hole directions are shown in Figure 1. 


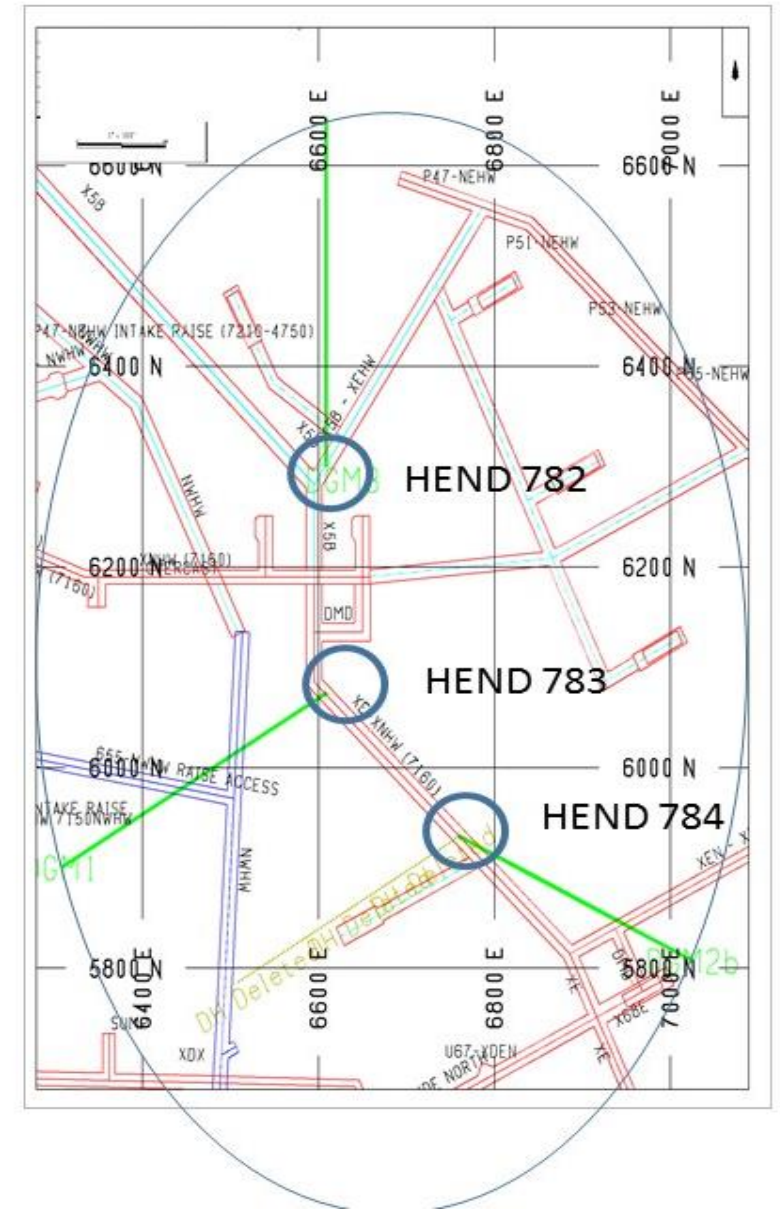

Figure 1 Plan showing hole layout for the stress determination

The stress determination comprising the four tests covered an area of approximately $40,000 \mathrm{~m}^{2}$, hence there was considerable interest in how the measurements would compare in orientation and magnitude.

\subsection{Test 782, 1549 below ground level (bgl)}

Subsampling was undertaken on the core. The subsample directions are firstly determined according to the core assuming it is vertical (Table 1), then for analysis the subsample directions are converted into mine orientations.

\section{Table 1 Subsample orientation HEND 0782}

\begin{tabular}{cc}
\hline $\begin{array}{c}\text { Relative to a vertical axis } \\
\text { (trend/plunge) }\end{array}$ & $\begin{array}{r}\text { HEND } 0782 \text { orientation in space } \\
\text { (trend/plunge) }\end{array}$ \\
\hline $000^{\circ} / 90^{\circ}$ & $003^{\circ} / 60^{\circ}$ \\
$180^{\circ} / 00^{\circ}$ & $183^{\circ} / 30^{\circ}$ \\
$090^{\circ} / 00^{\circ}$ & $93^{\circ} / 0^{\circ}$ \\
$135^{\circ} / 00^{\circ}$ & $134^{\circ} / 21^{\circ}$ \\
$180^{\circ} / 45^{\circ}$ & $183^{\circ} / 75^{\circ}$ \\
$270^{\circ} / 45^{\circ}$ & $300^{\circ} / 38^{\circ}$ \\
\hline
\end{tabular}




\subsubsection{Summary of test results 782}

In all tests undertaken, modulus, Poisson's Ratio and density are recorded. The geomechanical results for the test 782 from 1,549 $\mathrm{m}$ bgl are summarised in Table 2 .

Table 2 Summary of rock mechanics data for test 782 samples recovered from 1,549 m bgl

\begin{tabular}{cccccc}
\hline Sample & $\begin{array}{c}\text { Static modulus } \\
(\text { GPa })\end{array}$ & $\begin{array}{c}\text { Poisson's } \\
\text { Ratio }\end{array}$ & $\begin{array}{c}\text { Dynamic modulus } \\
(\mathbf{G P a})\end{array}$ & $\begin{array}{c}\text { Density } \\
\left(\mathbf{t} / \mathbf{m}^{3}\right)\end{array}$ & $\begin{array}{c}\text { Length } \\
(\mathbf{m m})\end{array}$ \\
\hline A1 & 57.3 & 0.146 & 66.3 & 2.57 & 37.50 \\
A2 & 58.6 & 0.176 & 72.9 & 2.52 & 37.50 \\
A3 & 57.7 & 0.158 & 59.9 & 2.53 & 45.20 \\
B1 & 64.3 & 0.165 & 68.5 & 2.57 & 40.55 \\
B4 & 52.3 & 0.138 & 60.3 & 2.55 & 40.80 \\
B3 & 50.1 & 0.175 & 61.9 & 2.55 & 38.90 \\
C1 & 62.5 & 0.167 & 70.2 & 2.56 & 39.00 \\
C2 & 66.6 & 0.15 & 75.1 & 2.58 & 40.50 \\
C4 & 57.8 & 0.22 & 67.7 & 2.56 & 40.10 \\
D1 & 58.7 & 0.188 & 74.4 & 2.57 & 38.30 \\
D2 & 55.0 & 0.185 & 70.5 & 2.56 & 38.40 \\
D3 & 59.1 & 0.157 & 67.5 & 2.57 & 38.60 \\
E1 & 60.9 & 0.200 & 69.5 & 2.54 & 45.20 \\
E2 & 52.7 & 0.181 & 65.3 & 2.54 & 44.90 \\
E3 & 57.9 & 0.219 & 64.7 & 2.56 & 45.10 \\
F1 & 63.6 & 0.209 & 73.7 & 2.54 & 43.40 \\
F3 & 60.7 & 0.207 & 68.9 & 2.56 & 42.90 \\
Average & 58.6 & 0.179 & 68.1 & 2.55 & 41.23 \\
Maximum & 66.6 & 0.220 & 75.1 & 2.58 & 45.20 \\
Minimum & 50.1 & 0.138 & 59.9 & 2.52 & 37.50 \\
Standard & & & & & \\
Deviation & 4.3 & 0.025 & 4.5 & 0.02 & 2.86 \\
\hline
\end{tabular}

The results show that the modulus, density and Poisson's Ratio are all consistent with a porphyry deposit. The porphyry behaves closely to an isotropic material. The samples are generally strong; a rough UCS estimation would be around $120 \mathrm{MPa}$. The difference between dynamic and static modulus suggests the natural defects in samples have minor to moderate influence on the rock mass.

\subsubsection{In situ stress of 782-DRA}

The results of the stress measurement are summarised in Table 3 and Figure 2. This shows that the maximum principal stress is interpreted to be sub-horizontal and oriented in a southeast direction. The stress was calculated to be $44.4 \mathrm{MPa}$. The intermediate principal stress is oriented sub-vertical at $235^{\circ} / 77^{\circ}$ and the magnitude is $37.4 \mathrm{MPa}$. The minimum principal stress is oriented towards $48^{\circ} / 13^{\circ}$ and has a magnitude of $22.9 \mathrm{MPa}$. The vertical stress calculated from the stress vectors is around $3 \mathrm{MPa}$ lower than 
calculated overburden stress, which is $39.6 \mathrm{MPa}$. The $\mathrm{k}$ ratio $=1.94: 1$. The difference might be due to error introduced by analysis, density anisotropy, induced stress from surrounding construction and/or local geological profile. The difference is considered low.

There is a difference between $\sigma_{1}$ and $\sigma_{2}$ in magnitude, however, swapping can occur. The dominant stress directions appear consistent with the fault/shear system reported for the dominant structures at Henderson.

Table 3 Stress results for HEND 0782

\begin{tabular}{cccc}
\hline Stress & Trend & Plunge & $\mathrm{MPa}$ \\
\hline$\sigma_{1}$ & 138 & 2 & 44.4 \\
$\sigma_{2}$ & 235 & 77 & 37.4 \\
$\sigma_{3}$ & 48 & 13 & 22.9 \\
$\sigma_{1}: \sigma_{2}: \sigma_{3}$ & & $1.94: 1.63: 1.00$ & \\
\hline & & &
\end{tabular}

Figure 2 Principal stress directions for HEND 0782

\subsection{Test $784 \mathrm{~S}, 1,614 \mathrm{~m} \mathrm{bgl}$ and Test $784 \mathrm{D}, 1637 \mathrm{bgl}$}

Tests were conducted on the core from the same hole designated $S$ and $D$, representing 'shallow' and 'deep'. The depths of the samples below surface were respectively 1,614 and 1,673 m.

Subsampling was undertaken on the core. The subsample directions are firstly determined according to the core, assuming it is vertical (Table 4), then for analysis the subsample directions are converted into mine orientations.

Table 4 Subsample directions for HEND $0784 \mathrm{~S}$ and 784D

\begin{tabular}{cc}
\hline $\begin{array}{c}\text { Relative to a vertical axis } \\
\text { (trend/plunge) }\end{array}$ & $\begin{array}{r}\text { HEND } 0784 \text { orientation in space } \\
\text { (trend/plunge) }\end{array}$ \\
\hline $000^{\circ} / 90^{\circ}$ & $114^{\circ} / 65^{\circ}$ \\
$180^{\circ} / 00^{\circ}$ & $294^{\circ} / 25^{\circ}$ \\
$090^{\circ} / 00^{\circ}$ & $24^{\circ} / 0^{\circ}$ \\
$135^{\circ} / 00^{\circ}$ & $246^{\circ} / 17^{\circ}$ \\
$180^{\circ} / 45^{\circ}$ & $294^{\circ} / 70^{\circ}$ \\
$270^{\circ} / 45^{\circ}$ & $47^{\circ} / 40^{\circ}$ \\
\hline
\end{tabular}


The geomechanical results from the testing of the subsamples recovered from 1,614 $\mathrm{m} \mathrm{bgl}$ are presented in Table 5 and the results from 1,637 $\mathrm{m}$ bgl are listed in Table 6 .

Table 5 Rock mechanics test results from subsamples recovered from HEND $78_{4} \mathrm{~S}$

\begin{tabular}{cccccc}
\hline Sample & $\begin{array}{c}\text { Static } \\
\text { modulus } \\
\text { (GPa) }\end{array}$ & $\begin{array}{c}\text { Poisson's } \\
\text { Ratio }\end{array}$ & $\begin{array}{c}\text { Dynamic } \\
\text { modulus } \\
\text { (GPa) }\end{array}$ & $\begin{array}{c}\text { Density } \\
\left(\mathbf{t} / \mathbf{m}^{3}\right)\end{array}$ & $\begin{array}{c}\text { Length } \\
(\mathbf{m m})\end{array}$ \\
\hline A2 & 34.1 & 0.089 & 48.4 & 2.51 & 38.00 \\
A4 & 40.6 & 0.138 & 47.0 & 2.45 & 38.40 \\
A5 & 74.3 & 0.12 & 54.7 & 2.57 & 37.80 \\
B1 & 38.1 & 0.162 & 48.8 & 2.51 & 38.10 \\
B2 & 70.4 & 0.122 & 73.5 & 2.66 & 37.20 \\
B4 & 35.9 & 0.11 & 45.5 & 2.49 & 39.30 \\
C2 & 36.2 & 0.142 & 44.3 & 2.44 & 39.10 \\
C3 & 48.9 & 0.172 & 48.9 & 2.47 & 38.60 \\
C4 & 38.7 & 0.15 & 46.8 & 2.49 & 37.70 \\
D2 & 32.8 & 0.135 & 43.9 & 2.48 & 38.10 \\
D3 & 44.9 & 0.173 & 47.8 & 2.46 & 38.30 \\
E1 & 44.9 & 0.175 & 46.0 & 2.46 & 39.40 \\
E2 & 34.9 & 0.126 & 38.3 & 2.47 & 37.20 \\
E3 & 26.2 & 0.156 & 34.2 & 2.45 & 38.00 \\
F1 & 37.5 & 0.148 & 51.7 & 2.52 & 37.90 \\
F2 & 40 & 0.189 & 48.4 & 2.49 & 37.70 \\
F3 & 38.4 & 0.158 & 35.4 & 2.46 & 37.00 \\
Average & 42.7 & 0.149 & 47.3 & 2.49 & 38.17 \\
Maximum & 74.3 & 0.189 & 73.5 & 2.66 & 39.40 \\
Minimum & 26.2 & 0.110 & 34.2 & 2.44 & 37.00 \\
Standard deviation & 12.3 & 0.022 & 8.3 & 0.05 & 0.68 \\
\hline & & & & & \\
\hline
\end{tabular}


Table 6 Rock mechanics test results from subsamples recovered from HEND 784D

\begin{tabular}{cccccc}
\hline Sample & $\begin{array}{c}\text { Static } \\
\text { Modulus } \\
\text { (GPa) }\end{array}$ & $\begin{array}{c}\text { Poisson's } \\
\text { Ratio }\end{array}$ & $\begin{array}{c}\text { Dynamic } \\
\text { Modulus } \\
(\text { GPa })\end{array}$ & $\begin{array}{c}\text { Density } \\
\left(\mathbf{t} / \mathbf{m}^{3}\right)\end{array}$ & $\begin{array}{c}\text { Length } \\
(\mathbf{m m})\end{array}$ \\
\hline A2 & 58.7 & 0.192 & 56.2 & 2.59 & 39.40 \\
A3 & 63.3 & 0.21 & 65.5 & 2.60 & 38.70 \\
A5 & 58 & 0.182 & 55.1 & 2.60 & 38.70 \\
B2 & 56 & 0.182 & 60.7 & 2.59 & 38.20 \\
B3 & 60.4 & 0.194 & 70.3 & 2.61 & 38.50 \\
B4 & 58 & 0.19 & 62.3 & 2.58 & 38.90 \\
C1 & 65.8 & 0.187 & 68.2 & 2.59 & 36.80 \\
C3 & 63.2 & 0.179 & 70.2 & 2.60 & 38.20 \\
C4 & 62.7 & 0.196 & 63.6 & 2.57 & 39.00 \\
D1 & 60.2 & 0.193 & 65.8 & 2.59 & 38.40 \\
D2 & 67.6 & 0.186 & 65.8 & 2.59 & 38.30 \\
D3 & 70.8 & 0.161 & 72.2 & 2.60 & 37.30 \\
E1 & 58.3 & 0.118 & 70.8 & 2.60 & 40.10 \\
E3 & 61 & 0.191 & 70.0 & 2.59 & 39.00 \\
E4 & 62.1 & 0.18 & 64.8 & 2.58 & 40.50 \\
F1 & 51.6 & 0.152 & 61.6 & 2.59 & 38.40 \\
F2 & 48.4 & 0.178 & 66.0 & 2.59 & 41.30 \\
F3 & 62.4 & 0.209 & 66.7 & 2.59 & 38.50 \\
Average & 60.5 & 0.182 & 65.3 & 2.59 & 38.79 \\
Maximum & 70.8 & 0.210 & 72.2 & 2.61 & 41.30 \\
Minimum & 48.4 & 0.118 & 55.1 & 2.57 & 36.80 \\
Standard deviation & 5.2 & 0.021 & 4.7 & 0.01 & 1.03 \\
\hline & & & & & \\
\hline
\end{tabular}

\subsubsection{Summary of test results $784 \mathrm{~S}$ and $784 \mathrm{D}$}

The results of 784S and 784D show that the density remains similar to the value in shallower samples from 782. The static and dynamic modulus of 784S are both 15-20 GPa lower than the value of 784D, which has similar value with the shallower samples 782. The Poisson's Ratio of 784S is also slightly lower, with the value of 0.15 . The sample strength of $784 \mathrm{~S}$ is assumed to be lower than $1,549 \mathrm{~m}$ bgl. The rough estimation of UCS of 784S would be set around 80-110 MPa. The estimated UCS of 784D would be around $120 \mathrm{MPa}$. 


\subsubsection{In situ stress of HEND $784 S-D R A$}

The results of the testing to determine the in situ stress using DRA for HEND 784S are shown in Figure 3 and Table 7. The results show that the maximum principal stress has an orientation of $319^{\circ} / 61^{\circ}$, the intermediate stress is oriented towards $129^{\circ} / 28^{\circ}$ and the minimum principal stress is sub-horizontally with an orientation of $221^{\circ} / 4^{\circ}$. The $\mathrm{k}$ ratio is $1.38: 1$, which is lower than for the shallow samples. The values of intermediate and minimum stresses are very close, the difference is $1.4 \mathrm{MPa}$. The difference is within an analysis error range; therefore, they can be considered as same. The vertical stress calculated from the stress vectors is $40.7 \mathrm{MPa}$, which is $0.5 \mathrm{MPa}$ lower than the calculated overburden stress based on the depth below surface and the average density. This is a good result.

However, there is a rotation in $\sigma_{1}$ versus $\sigma_{2}$ compared with the previous results.

\section{Table 7 Principal stress directions for HEND $0784 \mathrm{~S}$}

\begin{tabular}{cccc}
\hline Stress & Trend & Plunge & $\mathrm{MPa}$ \\
\hline$\sigma_{1}$ & 319 & 62 & 43.1 \\
$\sigma_{2}$ & 129 & 28 & 32.5 \\
$\sigma_{3}$ & 222 & 4 & 31.1 \\
$\sigma_{1}: \sigma_{2}: \sigma_{3}$ & & $1.38: 1.04: 1.00$ & \\
\hline & & & \\
\hline
\end{tabular}

\section{Figure 3 Stress orientations for HEND $0784 \mathrm{~S}$}

\subsubsection{In situ stress of HEND 784D - DRA}

The results of the testing to determine the in situ stress using DRA for HEND 784D are shown in Table 8 and Figure 4. The results show that the maximum principal stress has an orientation of $166^{\circ} / 17^{\circ}$, the intermediate stress is oriented towards $303^{\circ} / 67^{\circ}$ and the minimum principal stress is sub-horizontally with an orientation of $72^{\circ} / 15^{\circ}$. The $\mathrm{k}$ ratio is $1.36: 1$, which is also lower than for the shallow samples. The values of intermediate and minimum stresses are very close, the difference is $2.5 \mathrm{MPa}$. The difference is within an analysis error range; therefore, they can be considered as same. The vertical stress calculated from the stress vectors is $38.7 \mathrm{MPa}$, which is $4 \mathrm{MPa}$ lower than the calculated overburden stress based on the depth below surface and the average density. This is not as good as HEND 784S but is still a good result.

The orientation of the stresses however, is similar to HEND 782. 
Table 8 Principal stress results for HEND 784D

\begin{tabular}{cccc}
\hline Stress & Trend & Plunge & MPa \\
\hline$\sigma_{1}$ & 166 & 17 & 48.2 \\
$\sigma_{2}$ & 303 & 67 & 37.9 \\
$\sigma_{3}$ & 72 & 15 & 35.4 \\
$\sigma_{1}: \sigma_{2}: \sigma_{3}$ & \multicolumn{3}{c}{$1.36: 1.07: 1.00$} \\
\hline
\end{tabular}

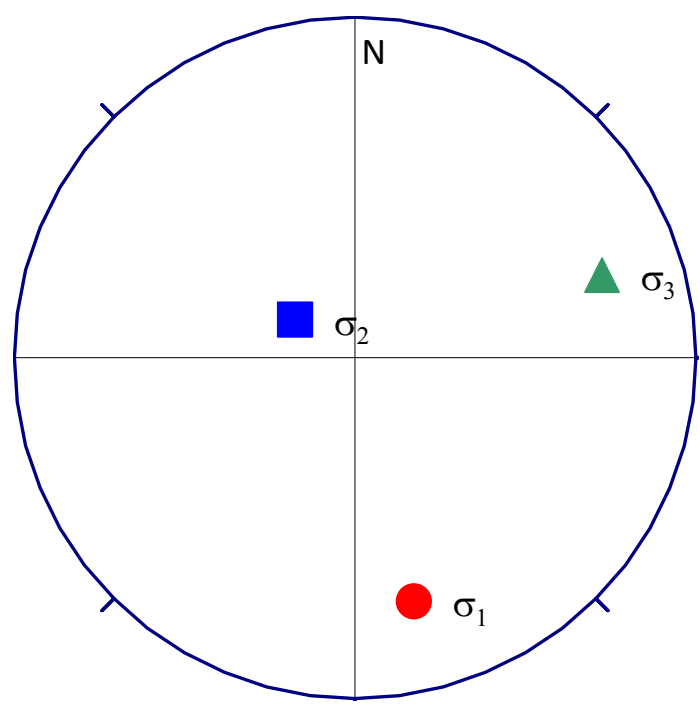

Figure 4 Stress orientations for HEND 784D

\subsection{Test $783,1,616 \mathrm{~m} \mathrm{bgl}$}

The results of a stress measurement program for samples recovered from borehole HEND 0783 are shown in Figure 5 and Table 9. The hole was oriented with trend and plunge of $240^{\circ} / 60^{\circ}$. Subsampling was undertaken on the core. The subsample directions are firstly determined according to the core assuming it is vertical (Table 10), then for analysis the subsample directions are converted into mine orientations.

Table 9 Principal stress directions for HEND 783

\begin{tabular}{cccc}
\hline Stress & Trend & Plunge & MPa \\
\hline$\sigma_{1}$ & 145 & 12 & 50.6 \\
$\sigma_{2}$ & 273 & 71 & 40.8 \\
$\sigma_{3}$ & 51 & 15 & 26.4 \\
$\sigma_{1}: \sigma_{2}: \sigma_{3}$ & \multicolumn{3}{c}{$1.92: 1.55: 1.00$} \\
\hline
\end{tabular}




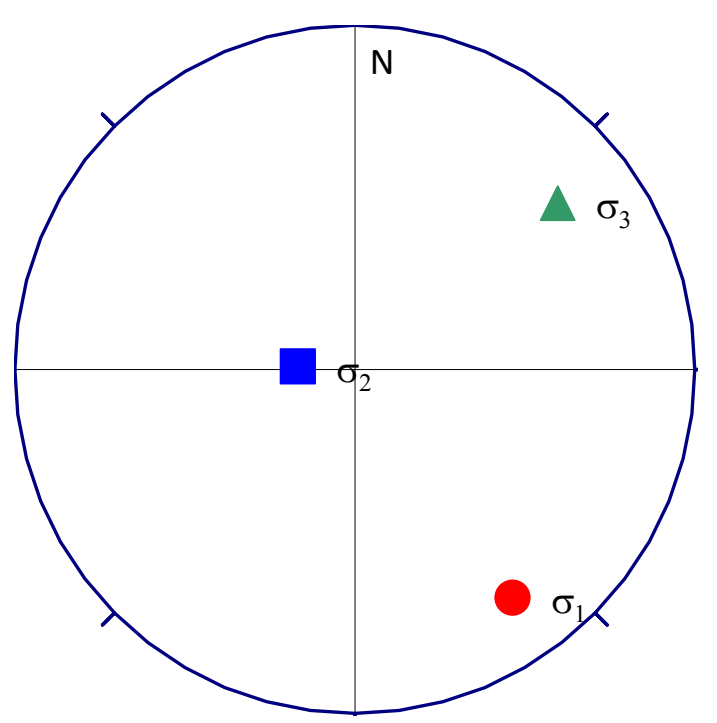

Figure 5 Stress orientations for HEND 0783

Table 10 Subsample directions for HEND 0783

\begin{tabular}{cc}
\hline $\begin{array}{c}\text { Relative to a vertical axis } \\
\text { (trend/plunge) }\end{array}$ & $\begin{array}{c}\text { HEND } 0784 \text { orientation in space } \\
\text { (trend/plunge) }\end{array}$ \\
\hline $000^{\circ} / 90^{\circ}$ & $240^{\circ} / 60^{\circ}$ \\
$180^{\circ} / 00^{\circ}$ & $60^{\circ} / 30^{\circ}$ \\
$090^{\circ} / 00^{\circ}$ & $150^{\circ} / 0^{\circ}$ \\
$135^{\circ} / 00^{\circ}$ & $11^{\circ} / 21^{\circ}$ \\
$180^{\circ} / 45^{\circ}$ & $60^{\circ} / 75^{\circ}$ \\
$270^{\circ} / 45^{\circ}$ & $177^{\circ} / 38^{\circ}$ \\
\hline
\end{tabular}

\subsubsection{Summary of test results 783}

In all tests undertaken, modulus and density are recorded. The geomechanical results for the test are summarised in Table 10.

The results show that the modulus, density and seismic velocity are all consistent with a porphyry deposit. The porphyry behaves closely to an isotropic material. The sample strength and deformation response is highly variable; a rough UCS estimation would be around $70 \mathrm{MPa}$. Part of the dissimilarity in the modulus is due to the level of confinement and the heterogeneity. 
Table 11 Rock properties from HEND 0783 samples recovered from 1,616 m bgl

\begin{tabular}{cccccc}
\hline Sample & $\begin{array}{c}\text { Static modulus } \\
(\mathbf{G P a})\end{array}$ & $\begin{array}{c}\text { Velocity } \\
(\mathbf{m} / \mathbf{s})\end{array}$ & $\begin{array}{c}\text { Density } \\
\left(\mathbf{t} / \mathbf{m}^{3}\right)\end{array}$ & $\begin{array}{c}\text { Length } \\
(\mathbf{m m})\end{array}$ & $\begin{array}{c}\text { Confinement } \\
(\mathbf{M P a})\end{array}$ \\
\hline A1 & 46.1 & 3,540 & 2.29 & 38.8 & 30 \\
\hline A4 & 72 & 3,674 & 2.33 & 38.8 & 30 \\
A5 & 46.3 & 3,917 & 2.26 & 39.8 & 30 \\
\hline B1 & 27.3 & 3,832 & 2.34 & 37.4 & 0 \\
B2 & 38.1 & 3,431 & 2.30 & 35.2 & 50 \\
B3 & 109.6 & 4,783 & 2.42 & 35.2 & 50 \\
B4 & 126.1 & 4,582 & 2.40 & 35.1 & 50 \\
C1 & 26.7 & 4,039 & 2.31 & 37.4 & 0 \\
C3 & 116.2 & 4,582 & 2.45 & 35.1 & 50 \\
C4 & 118 & 4,656 & 2.39 & 35.0 & 50 \\
D3 & 123.1 & 4,848 & 2.45 & 35.0 & 50 \\
D4 & 113.7 & 4,199 & 2.38 & 35.0 & 50 \\
E2 & 16.4 & 3,446 & 2.29 & 38.8 & 30 \\
E4 & 69.1 & 3,750 & 2.31 & 35.0 & 50 \\
F1 & 61 & 3,446 & 2.35 & 39.0 & 30 \\
F2 & 74.6 & 3,477 & 2.33 & 39.0 & 30 \\
F4 & 50.4 & 4,048 & 2.30 & 39.0 & 30 \\
\hline Average & 72.6 & 4,015 & 2.34 & 37.0 & \\
Maximum & 126.1 & 4,848 & 2.45 & 39.8 & \\
\hline Minimum & 16.4 & 3,431 & 2.26 & 35.0 & \\
\hline Standard deviation & 36.7 & 491 & 0.056 & 1.9 & \\
\hline & & & & & \\
\hline
\end{tabular}

\subsubsection{In situ stress of $783-D R A$}

The results of the stress measurement are summarised in Figure 5 and Table 9.

This shows that the maximum principal stress is interpreted to be sub-horizontal and oriented in a southeast direction $\left(145^{\circ} / 12^{\circ}\right)$. The stress was calculated to be $50.6 \mathrm{MPa}$. The intermediate principal stress is oriented sub-vertically with a steep plunge at $273^{\circ} / 71^{\circ}$ and a magnitude is $40.8 \mathrm{MPa}$. The minimum principal stress is oriented sub-horizontally at $051^{\circ} / 15^{\circ}$ and has a magnitude of $26.4 \mathrm{MPa}$. The vertical stress calculated from the stress vectors is around $2 \mathrm{MPa}$ higher than calculated overburden stress, which is 38.1 MPa. The $\mathrm{k}$ ratio $=1.92: 1$. The difference is considered low.

The dominant stress directions appear consistent with the fault/shear system reported for the dominant structures at Henderson.

\subsubsection{Load deformation response}

The testing shows that the stress memory can be recovered from samples, subject to confinement. An example of the stress strain response for two samples, B1 and B2, with same orientation/location and similar stiffness is presented in Figure 6. 
Sample B1 was tested uniaxially and sample B2 was subjected to $50 \mathrm{MPa}$ confinement. Figure 6(a) shows the confinement has significantly increased the tangent moduli and strength of B2. The UCS of B1 is close to the maximum applied stress, $47 \mathrm{MPa}$, which is only slightly higher than the overburden stress. Since the in situ stress in B direction can be 0.5-2 times of overburden stress, it is difficult to know whether the applied stress is higher than the in situ stress. To achieve higher applied stress, the confinement increases the strength of sample and enables one to achieve a stress much higher than estimated unconfined stress, without shifting the inflection point. In Figure $6(\mathrm{~b})$ the inflection points of B2 are located at a similar stress level with those of B1. The important conclusion is that the testing with confinement increases the strength at which a sample will fail but does not remove the stress memory.

Tangent Modulus

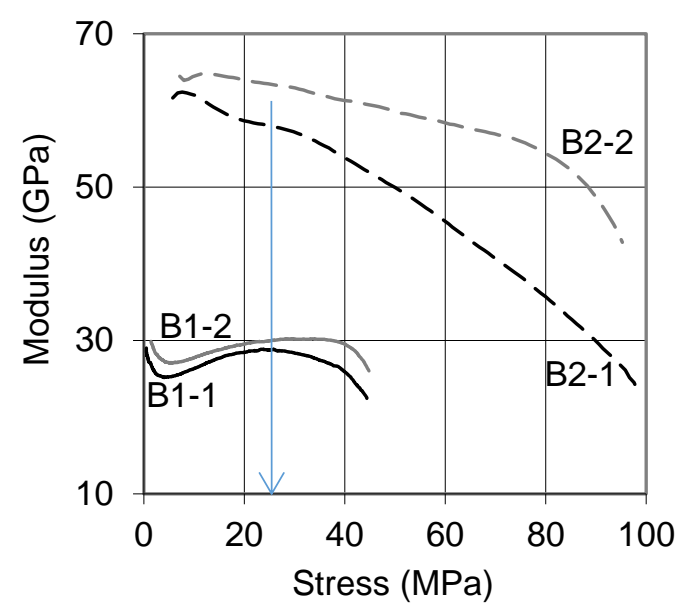

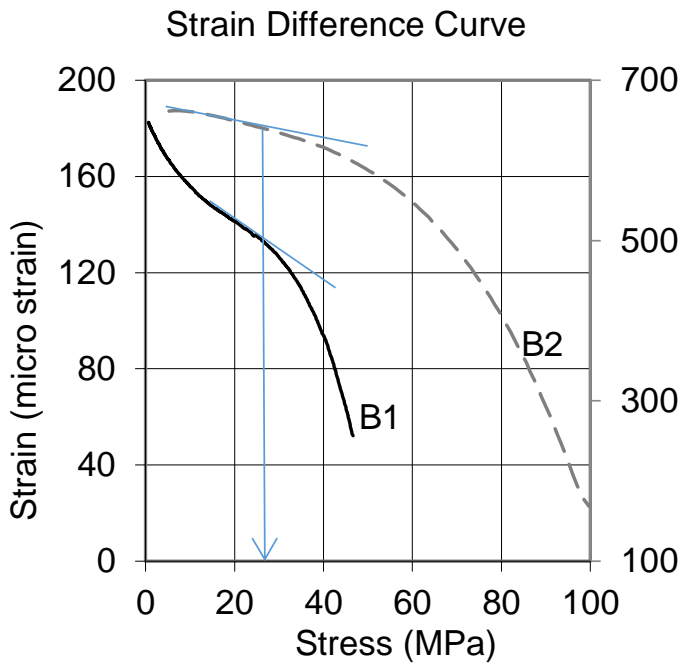

Figure 6 (a) $B_{1-1}$ represents the response of first cycle at sample $B_{1}$. The tangent moduli of $B_{1}$ is much lower than it of $B_{2}$. The maximum load subjected to $B_{1}$ is $47 \mathrm{MPa}$, which is very close to the UCS. The maximum stress difference $\left(\sigma_{1}-\sigma_{3}\right)$ subjected to $\mathrm{B}_{2}$ is $100 \mathrm{MPa}$, which is also close to failure stress; (b) although the stiffness and strength of $B_{2}$ increased significantly due to the confinement, the inflection points at B1 and B2 occur at similar stress level

\subsection{Stress gradient}

For completeness a graph of the stress change with depth is shown in Figure 7Figure. This suggests $\sigma_{2}=$ $0.027 \times \mathrm{D}$ which is gravitational, and $\sigma_{3}=0.016 \times \mathrm{D}$. 


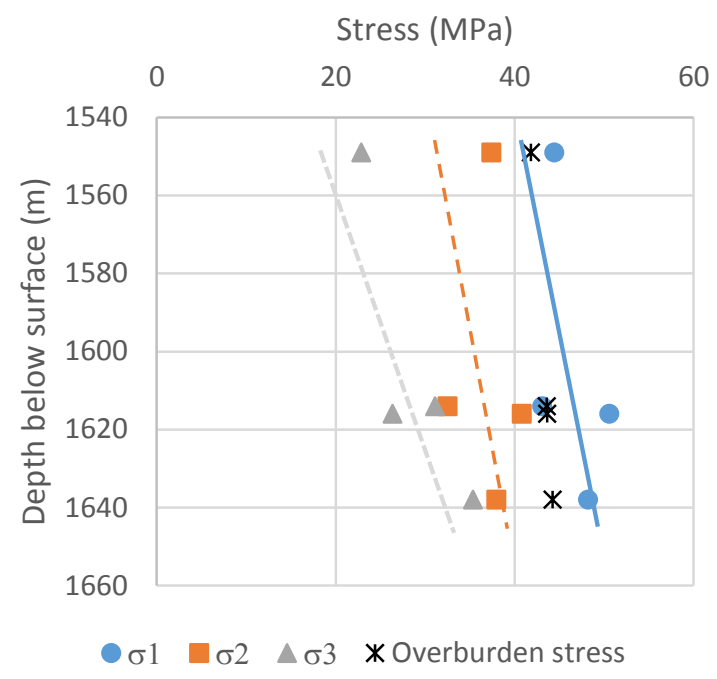

Figure 7 Stress gradient

\section{$4 \quad$ Summary and conclusions}

The dominant stresses $\left(\sigma_{1}\right.$ and $\left.\sigma_{2}\right)$ are sub-horizontal and sub-vertical respectively, with $\sigma_{1}$ oriented southeast-northwest and $\sigma_{3}$ predominantly northeast, which is consistent with the formation of an intrusive orebody into an extensional regime. The rock is only mildly anisotropic and this can be ignored in stress analysis. There is good agreement with the vertical stress component derived from the tests and the expected overburden stress. We would conclude that this is a low to moderately stressed rock mass.

Figure 8 summarises the stress orientations for the testing and three major faults/shear planes at Henderson. 


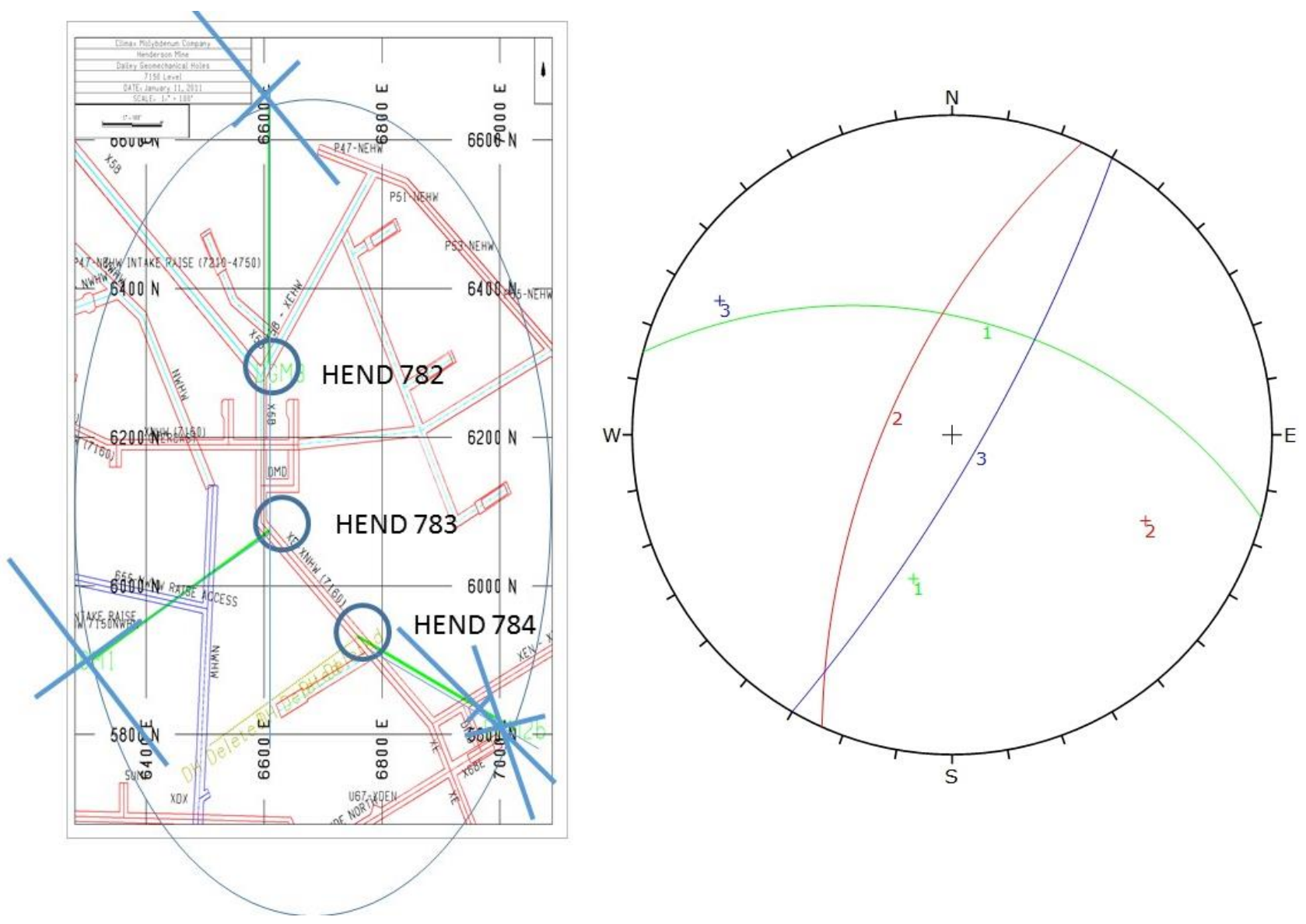

Figure 8 The large crosses show dominant stress directions at each testing site. The stereonet plot shows the structures of fault and shear plane

\section{Acknowledgements}

The confined test work was conducted by Professor Boris Tarasov and the unconfined test work was conducted by $\mathrm{Dr}$ Ariel Hsieh. The support of Climax Henderson, Freeport-McMoran is gratefully acknowledged.

\section{References}

Dight, PM \& Snyman, LA 2010, 'Stress measurement for St Barbara Mines Gwalia Deeps project - one of the world's deepest underground haulage mines', Mining Technology, vol. 119, no. 4, pp. 246-254.

Dight, PM, Tarasov, BG, Hsieh, A \& Dyskin, AV 2013, 'Determining stress memory under confinement', in T Ito (ed.), Proceedings of the Sixth International Symposium on In-Situ Rock Stress, International Society for Rock Mechanics, Lisbon.

Engelder, T, Plumb, R \& Sbar, M 1984, 'Changes in in situ ultrasonic properties of rock on strain relaxation', International Journal of Rock Mechanics and Mining Sciences \& Geomechanics Abstracts, vol. 21, no. 2, pp. 75-82.

Hsieh, A 2014, 'In-situ stress reconstruction using rock memory', PhD thesis, The University of Western Australia Perth.

Nur, A 1971, 'Effects of stress on velocity anisotropy in rocks with cracks', Journal of Geophysical Research, vol. 76, no. 8.

Nur, A \& Simmons, G 1969, 'Stress-induced velocity anisotropy in rock: an experimental study', Journal of Geophysical Research, vol. 74, no. 27.

Plumb, R, Engelder, T \& Yale, D 1984, 'Near surface in situ stress: 3. Correction with microcrack fabric within the New Hampshire granites', Journal of Geophysical Research, vol. 89, no. B11.

Sayers, CM 1990, 'Orientation of microcracks formed in rocks during strain relaxation', International Journal of Rock Mechanics and Mining Sciences \& Geomechanics, vol. 27, no. 5.

Yamamoto, K, Kuwahara, Y, Kato, N \& Hirasawa, T 1990, 'Deformation Rate Analysis: A new method for in situ stress estimation from inelastic deformation of rock samples under uni-axial compressions', Tohoku Geophysics Journal, vol. 33, no. 2, pp. 127-147. 